\title{
Erratum to: Estimation of actual evapotranspiration for a drip-irrigated Merlot vineyard using a three-source model
}

\author{
Carlos Poblete-Echeverría · Samuel Ortega-Farias
}

Published online: 22 February 2011

(C) Springer-Verlag 2011

\section{Erratum to: Irrig Sci}

\section{DOI 10.1007/s00271-009-0183-y}

The authors would like to make following corrections in the Eqs. 3, 4, and 5. The values of $\mathrm{PM}^{\mathrm{c}}, \mathrm{PM}^{\mathrm{s}}, \mathrm{PM}^{\mathrm{bs}}$ are computed by the following equations:

$$
\mathrm{PM}^{\mathrm{c}}=\frac{\Delta A+\left[\frac{\rho C_{\mathrm{p}} D-\Delta r_{\mathrm{a}}^{\mathrm{c}} A_{\mathrm{s}}}{r_{\mathrm{a}}^{\mathrm{a}}+r_{\mathrm{a}}^{\mathrm{c}}}\right]}{\Delta+\gamma\left[\frac{1+r_{\mathrm{s}}^{\mathrm{c}}}{r_{\mathrm{a}}^{\mathrm{a}}+r_{\mathrm{a}}^{\mathrm{c}}}\right]} \quad \mathrm{PM}^{\mathrm{c}}=\frac{\Delta A+\left[\frac{\rho C_{\mathrm{p}} D-\Delta r_{\mathrm{a}}^{\mathrm{c}} A_{\mathrm{s}}}{r_{\mathrm{a}}^{\mathrm{a}}+r_{\mathrm{a}}^{\mathrm{c}}}\right]}{\Delta+\gamma\left[1+\frac{r_{\mathrm{s}}^{\mathrm{c}}}{r_{\mathrm{a}}^{\mathrm{a}}+r_{\mathrm{a}}^{\mathrm{c}}}\right]}
$$

$\mathrm{PM}^{\mathrm{s}}=\frac{\Delta A+\left[\frac{\rho C_{\mathrm{p}} D-\Delta r_{\mathrm{a}}^{\mathrm{s}} A_{\mathrm{c}}}{r_{\mathrm{a}}^{\mathrm{a}}+r_{\mathrm{a}}^{\mathrm{s}}}\right]}{\Delta+\gamma\left[\frac{1+r_{\mathrm{s}}^{\mathrm{s}}}{\mathrm{r}_{\mathrm{a}}^{\mathrm{a}}+r_{\mathrm{a}}^{\mathrm{s}}}\right]}$

$$
\mathrm{PM}^{\mathrm{s}}=\frac{\Delta A+\left[\frac{\rho C_{\mathrm{p}} D-\Delta r_{\mathrm{a}}^{\mathrm{s}} A_{\mathrm{c}}}{r_{\mathrm{a}}^{\mathrm{a}}+r_{\mathrm{a}}^{\mathrm{s}}}\right]}{\Delta+\gamma\left[1+\frac{r_{\mathrm{s}}^{\mathrm{s}}}{r_{\mathrm{a}}^{\mathrm{a}}+r_{\mathrm{a}}^{\mathrm{s}}}\right]}
$$

$\mathrm{PM}^{\mathrm{bs}}=\frac{\Delta A+\left[\frac{\rho C_{\mathrm{p}} D}{r_{\mathrm{a}}^{\mathrm{a}}+r_{\mathrm{a}}^{\mathrm{bs}}}\right]}{\Delta+\gamma\left[\frac{1+r_{\mathrm{s}}^{\mathrm{bs}}}{r_{\mathrm{a}}^{\mathrm{a}}+r_{\mathrm{a}}^{\mathrm{bs}}}\right]}$

$$
\mathrm{PM}^{\mathrm{bs}}=\frac{\Delta A_{\mathrm{bs}}+\left[\frac{\rho C_{\mathrm{p}} D}{r_{\mathrm{a}}^{\mathrm{a}}+r_{\mathrm{a}}^{\mathrm{bs}}}\right]}{\Delta+\gamma\left[1+\frac{r_{\mathrm{s}}^{\mathrm{bs}}}{r_{\mathrm{a}}^{\mathrm{a}}+r_{\mathrm{a}}^{\mathrm{bs}}}\right]}
$$

where $A$ is the total energy available above the vineyard $\left(\mathrm{W} \mathrm{m}{ }^{-2}\right), A_{\mathrm{s}}$ is the available energy of soil under vine canopy ( $\left.\mathrm{W} \mathrm{m}^{-2}\right), A_{\mathrm{c}}$ is the available energy of vine canopy $\left(\mathrm{W} \mathrm{m}{ }^{-2}\right), A_{\mathrm{bs}}$ is the available energy of bare soil $\left(\mathrm{W} \mathrm{\textrm {m } ^ { - 2 }}\right)$ $\left(A_{\mathrm{bs}}=\mathrm{Rn}-G_{\mathrm{bs}}\right), \Delta$ is the slope of the vapor pressure versus temperature curve $\left(\mathrm{kPa}^{\circ} \mathrm{C}^{-1}\right), \mathrm{Cp}$ is the specific heat capacity of the air at constant pressure $\left(1,013 \mathrm{~J} \mathrm{~kg}^{-1}{ }^{\circ} \mathrm{C}^{-1}\right)$, $\rho$ is the air density $\left(\mathrm{kg} \mathrm{m}^{-3}\right), \gamma$ is the psychrometric constant $\left(\mathrm{kPa}{ }^{\circ} \mathrm{C}^{-1}\right), D$ is the water vapor deficit of the air at the reference height $\left(z_{\mathrm{r}}\right)(\mathrm{kPa}), r_{\mathrm{a}}^{\mathrm{c}}$ is the aerodynamic resistance of the vine from the leaf surface to mean surface flow height $\left(z_{\mathrm{m}}\right)\left(\mathrm{s} \mathrm{m}^{-1}\right), r_{\mathrm{a}}^{\mathrm{a}}$ is the aerodynamic resistance between $z_{\mathrm{m}}$ and $z_{\mathrm{r}}\left(\mathrm{s} \mathrm{m}^{-1}\right), r_{\mathrm{a}}^{\mathrm{bs}}$ is the aerodynamic resistance between the bare soil surface between rows and $z_{\mathrm{m}}$ $\left(\mathrm{s} \mathrm{m}^{-1}\right), r_{\mathrm{a}}^{\mathrm{s}}$ is the aerodynamic resistance between the soil under vine canopy and $z_{\mathrm{m}}\left(\mathrm{s} \mathrm{m}^{-1}\right), r_{\mathrm{s}}^{\mathrm{c}}$ is the canopy resistance $\left(\mathrm{s} \mathrm{m}^{-1}\right), r_{\mathrm{s}}^{\mathrm{s}}$ is the soil surface resistance under vine canopy $\left(\mathrm{s} \mathrm{m}^{-1}\right)$, and $r_{\mathrm{s}}^{\mathrm{bs}}$ is the soil surface resistance between rows $\left(\mathrm{s} \mathrm{m}^{-1}\right)$.
The online version of the original article can be found under doi:10.1007/s00271-009-0183-y.

C. Poblete-Echeverría $\cdot$ S. Ortega-Farias $(\square)$

Facultad de Ciencias Agrarias, Centro de Investigación y,

Transferencia en Riego y Agroclimatología (CITRA),

Universidad de Talca, Talca, Chile

e-mail: sortega@utalca.cl 